\title{
Production and Nutrient Status of Whitetop
}

\author{
ALAN L. SMITH
}

Highlight: Post-flowering production of whitetop (Scolochloa festucacea [Willd.] Link.) was greater from burned and mowed sites than from undisturbed sites. Production from grazed stands was equal to that from undisturbed sites. Whitetop growth was initiated earlier on burned sites resulting in an earlier flowering time. Phenological differences in $N$ content of the plant could be detected relative to water depth in the pothole. Nitrogen content decreased through flowering then increased. Potassium content decreased through the growing season. No concentration patterns were noted for other basic cations in the plant tissue relative to growth stage, site condition, or land-use practice. No relationship was ascertained between nutrient status of whitetop and land-use practice of the supporting site.

Whitetop (Scolochloa festucacea [Willd.] Link.) is an emergent hydrophytic grass (Fig. 1) of wetland communities in glaciated regions of the Central Lowlands and Great Plains physiographic provinces of northcentral United States and southcentral Canada (Martin and Uhler, 1939; Stewart and Kantrud, 1969). Wetland habitats of this area are mostly small, ephmeral to permanently inundated, ponds commonly called potholes (Smith et al., 1964). They are located within a youthful glacial landscape of poor drainage. These potholes were formed by iceblock basins and irregularly deposited till of Pleistocene glaciers (Flint, 1957).

Whitetop may be hayed in late July to early August when water levels drop in the potholes. The species is highly palatable to livestock but does not tolerate continued grazing pressure (Clarke and Tisdale, 1945; Smeins, 1967).

Whitetop production varies with soil types, depth, and duration of submergence and salinity (Cosby, 1964). Crude protein content of the herbage is high during early stages of flowering (Zagrabaev and Zenchenko, 1970) but

The author is presently plant ecologist, Environmental Service Group, Dames and Moore, Cincinnati, Ohio 45203.

The paper represents a portion of a doctoral dissertation submitted to the Department of Range Science, Texas A\&M University, December 1971. The author greatly acknowledges the Rob and Bessie Welder Wildlife Foundation, Sinton, Texas, for supporting final disposition of the dissertation.

Manuscript received February 28, 1972. both protein and $\mathrm{Ca}$ content decrease considerably after flowering (Clarke and Tisdale, 1945).

Estimates of whitetop productivity or nutrient status are not well documented. The objectives of this study were to (a) estimate production and nutrient status of whitetop herbage in stands which were undisturbed, burned, mowed, or grazed, and (b) evaluate seasonal changes in $\mathrm{N}$,
$\mathrm{Ca}^{++}, \mathrm{Mg}^{++} \mathrm{Na}^{+}$and $\mathrm{K}^{+}$content of the herbage.

\section{Methods and Materials \\ Production}

Post-flowering herbage production of whitetop was obtained during 1969 and 1970 from 26, randomly-selected stands. Treatments evaluated were undisturbed, burned, mowed, and grazed by livestock. Burning treatments were applied the previous fall after senescence. Mow treatments were applied in August prior to sampling the following growing season. Samples were collected between July 25 and August 15 both years. Plants were clipped at ground level in four $0.25 \mathrm{~m}^{2}$ quadrats and air-dried 1 week. Samples were then oven-dried $72 \mathrm{hr}$ at $105^{\circ}$ to $110^{\circ} \mathrm{C}$ and weights recorded.

Oven-dry whitetop herbage weight was

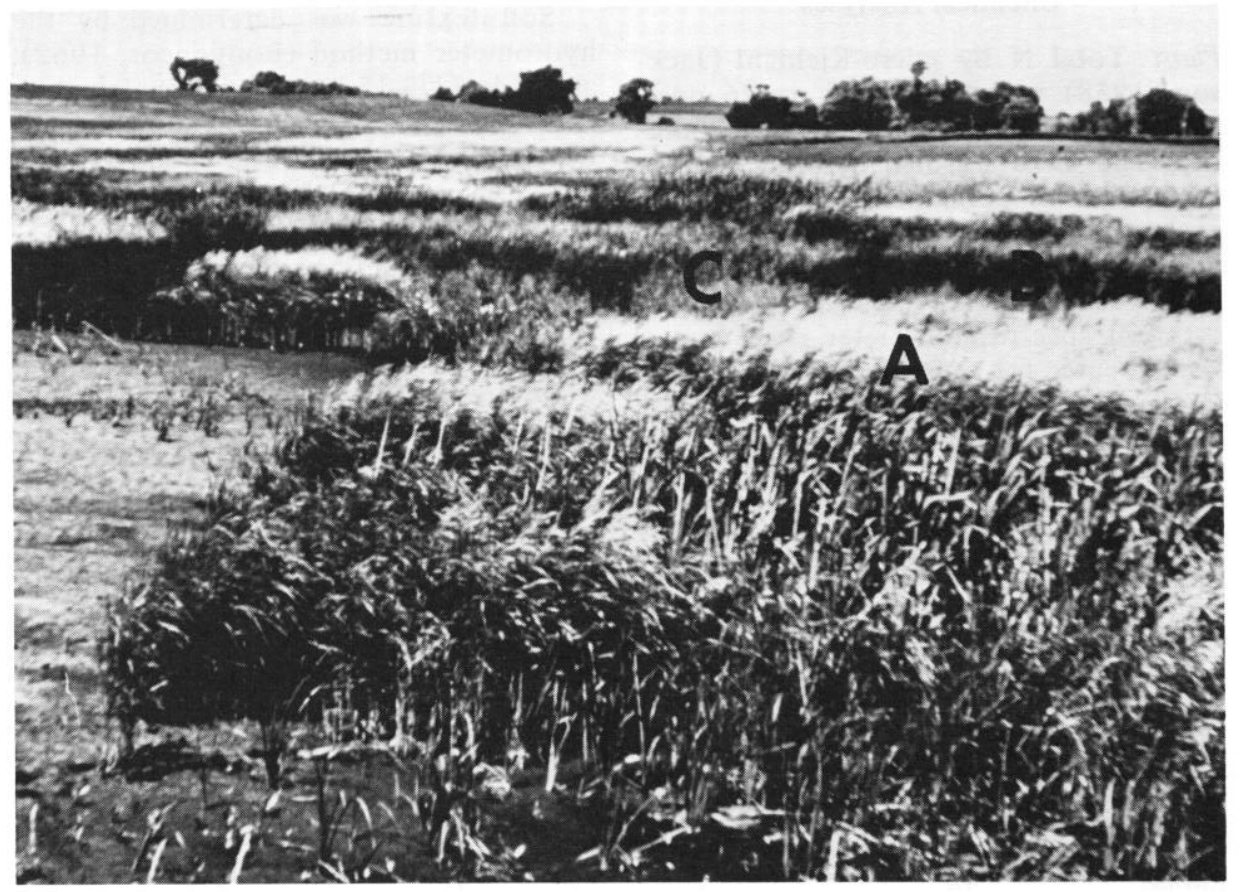

Fig. 1. Whitetop (A) growing in a North Dakota pothole which is fall burned annually. The grass commonly grows with other emergent hydrophytes such as bulrushes (B) and tall manna grass (C) in potholes which are inundated in early spring. 
estimated in relation to water depth in a stand near Buxton and another near Petersburg, N. Dak. The Buxton site was burned in the fall of 1968 and 1969. Plots were arranged in a randomized block design and stratificd across a water-depth gradient. Four blocks of 3.3 $\mathrm{x} 3.3 \mathrm{~m}$ plots were established for sampling June through August, with four 0.25 $\mathrm{m}^{2}$ subsamples clipped each sampling date at each of four water levels. The experiment was expanded in 1970 to estimate production from April through August. The Petersburg site was burned the fall of 1968 but not in 1969. Plots were delineated similar to those at Buxton and were sampled from June through August in 1969. The study was expanded in 1970 to include monthly sampling from May through August.

Water levels were measured in the potholes at both sites when monthly herbage production samples were collected to determine hydrological changes. Due to the unpredictable nature of the hydrology of these potholes, water levels are referred to as those measured in the study plots at the time they were delineated. Water levels at the Buxton sitc included no standing water at the first block, $8 \mathrm{~cm}$ at the second block, $15 \mathrm{~cm}$ at the third block, and $24 \mathrm{~cm}$ at the fourth block. No standing water was recorded in the first and second tiers of plots when the study was initiated at the Petersburg site. Five $\mathrm{cm}$ of water was standing in the third block and $8 \mathrm{~cm}$ of water in the fourth. Soil and water temperatures were recorded at the time of sampling during 1970.

\section{Chemical Analyses}

Plant-Total $\mathrm{N}$ by micro-Kjeldahl (Jackson, 1958) was determined on 26 postflowering, production samples of whitetop. The 1970 seasonal herbage samples from the two permanent sites also were analyzed.

Concentrations of $\mathrm{Ca}, \mathrm{Mg}, \mathrm{Na}$ and $\mathrm{K}$ ions were estimated with an atomic absorption spectrophotometer. Leaf tissue was prepared for analysis utilizing a modification of the wet-ash method outlined by Jackson (1958). One $\mathrm{g}$ of tissue was digested with a ternary acid mixture at $350^{\circ} \mathrm{C}$ in a $100 \mathrm{ml}$ volumetric flask. After digestion the flask was brought to volume

Table 1. Average oven-dry herbage production (kg/ha), nitrogen $(\%)$ and basic cations $(\%)$ by weight in whitetop tissue collected from 26 post-flowering stands in North Dakota during the 1969 and 1970 growing seasons.

\begin{tabular}{|c|c|c|c|c|c|c|c|}
\hline \multirow[b]{2}{*}{ Treatments } & \multirow{2}{*}{$\begin{array}{l}\text { Number of } \\
\text { stands }\end{array}$} & \multirow[b]{2}{*}{ Production } & \multicolumn{5}{|c|}{ Element in tissue } \\
\hline & & & $\mathrm{N}$ & $\mathrm{Ca}$ & $\mathrm{Mg}$ & $\mathrm{K}$ & $\mathrm{Na}\left(\times 10^{-2}\right)$ \\
\hline No disturbance & 8 & 7,480 & 1.02 & .12 & .08 & 1.2 & .54 \\
\hline Burned & 10 & 11,580 & 1.05 & .15 & .10 & 1.2 & .84 \\
\hline Mowed & 5 & 10,090 & 1.19 & .17 & .11 & 1.1 & .53 \\
\hline Grazed & 3 & 7,450 & 1.11 & .15 & .07 & 1.2 & .29 \\
\hline
\end{tabular}

with double distilled water.

Soil-Soil salinity by electrical conductivity (Jackson, 1958) and total carbonate (Bower and Wilcox, 1965) was determined on saturation extracts. Organic carbon was determined using the Walkley-Black method (Jackson, 1958).

The atomic absorption spectrophotometer was utilized for $\mathrm{Ca}, \mathrm{Mg}, \mathrm{Na}$ and $\mathrm{K}$ ion determinations of soil extracts. Extracts were prepared by a modification of Chapman's (1965) ammonium acetate ( $\mathrm{NH}_{4} \mathrm{OAc}$ ) extraction technique. Ten $\mathrm{g}$ of soil were saturated with $50 \mathrm{ml}$ of $1 \mathrm{~N}$ $\mathrm{NH}_{4} \mathrm{OAc}$ and placed on a shaker for 12 hr. Samples were filtered with an excess of solution and brought to $100 \mathrm{ml}$.

Soil texture was determined by the hydrometer method (Bouyoucos, 1962); available (1/3-15 atm) using matrix suction (Richards, 1965); and bulk density by weight to volume ratio (Blake, 1965).

\section{Results and Discussion}

\section{Herbage Production and Nutrient Status}

Whitetop is utilized as forage in the Northern Great Plains. In many areas, water levels drop sufficiently by late July and early August to permit haying. Herbage production during the study period varied from 3,080 to $15,080 \mathrm{~kg} / \mathrm{ha}$. Burning and mowing increased yield, while grazed stands produced herbage equal to protected stands.

Water level had little influence on whitetop production unless the pothole was dry the year round. Cosby (1964) reported high yields, $8,900 \mathrm{~kg} / \mathrm{ha}$, on soils where ponding occurred; production decreased $2,600 \mathrm{~kg} / \mathrm{ha}$ without ponding.

Production on burned stands averaged more than $11,500 \mathrm{~kg} / \mathrm{ha}$ and 10,090 $\mathrm{kg} / \mathrm{ha}$ on mowed stands (Table 1 ). Undisturbed stands produced only an average of 7,480 kg/ha. Production was not correlated with stem density (Smith, 1971). Burning and mowing resulted in more uniform distribution of whitetop stems, while undisturbed stands contained heavy litter accummulation. Litter accummulations often resulted in aggregations of stems in openings in the litter. Consequently, samples of high stem density but of low production were obtained.

Whitetop herbage production from grazed stands was equal to production from stands with no disturbance (Table 1). No estimates of acres/animal unit month were obtained relative to grazed potholes. Comparison of two potholes, one-half mile apart, indicated duration of grazing was an important factor. One stand was grazed continuously throughout the growing season (personal communication with local residents). A mean density of 51 stems $/ \mathrm{m}^{2}$ and a high density of slough sedge (Carex atherodes Spreng.) suggested that whitetop was grazed selectively. Continuous grazing would tend to deplete food reserves in the rhizomes and eventually eliminate the species from the stand. Smeins (1967) also reported whitetop decreases under intense, continuous grazing. The other stand was normally grazed at a high 
intensity for 4 to 6 weeks starting in mid-June, terminating with almost complete removal of aerial shoots. This stand was not grazed in 1970, the year it was sampled. Density of whitetop was 580 stems $/ \mathrm{m}^{2}$. This grazing system prevented litter accumulation and plants had sufficient time during the remainder of the growing season to develop rhizomes for the next season's growth.

Herbage $\mathrm{N}$ (\% oven-dry weight) ranged from 0.5 to $1.92 \%$ with a mean of $1.08 \%$ in late July and early August for all land use categories. No trends were noted in the relation of herbage $\mathrm{N}$ content to land use practice. Calcium was the most consistent basic cation with a range of 0.09 to $0.23 \%$ and a mean of $0.15 \%$. Magnesium ranged from 0.02 to $0.32 \%$ with a mean of $0.10 \%$. Potassium occurred in higher amounts than any other cation. It ranged from 0.8 to $2.3 \%$ with a mean of $1.18 \%$. Sodium occurred in least amounts with a range of 0.02 to $2 \times 10^{-2} \%$ and a mean of $0.62 \times 10^{-2} \%$.

No significant correlation was derived between edaphic factors and production. However, negative trends were noted for organic carbon, $\mathrm{Mg}$ and $\mathrm{K}$ ion content, and conductivity of soil extracts. The latter value was closer to significance than other variables. All other variables were positively correlated within the limits of this study. Since these potholes are depressions in the glacial till, they usually represent the lowest point of the local topography. Fluctuation of the water table, rate of siltation, and deposition of fertilizer from the surrounding agricultural lands could influence the factors estimated in this study.

\section{Production and Nutritional Changes}

Whitetop herbage production on the burned site (Buxton) (Table 2) indicated little influence of water depth on production during 1969. A significant difference $(\mathrm{p}<.05)$ was noted between the mean June and August production. This site was damaged by hail 3 days prior to the August clipping date. Significant production differences occurred among the first, third and fourth water levels from April through August, 1970. Significant differences were noted among the overall monthly mean production values in any given year. June production was 6,840 $\mathrm{kg} / \mathrm{ha}$ in 1969 but only $5,960 \mathrm{~kg} / \mathrm{ha}$ in 1970. July production increased 1,200 $\mathrm{kg} / \mathrm{ha}$ over June production in 1969 , while production increased about 3,000 $\mathrm{kg} / \mathrm{ha}$ for the same period in 1970 . These data indicate earlier and more rapid

Table 3. Comparison of seasonal productivity $(\mathrm{kg} / \mathrm{ha})$ of whitetop from four water levels in a pothole near Petersburg, North Dakota, following a fall burn and a season with no fall burn. ${ }^{1}$

\begin{tabular}{|c|c|c|c|c|c|}
\hline \multirow{2}{*}{$\begin{array}{l}\text { Treatment } \\
\text { and month }\end{array}$} & \multicolumn{5}{|c|}{ Water level $^{2}$} \\
\hline & 1 & 2 & 3 & 4 & Mean \\
\hline \multicolumn{6}{|c|}{ Burned fall, 1968, and sampled 1969} \\
\hline $\begin{array}{l}\text { June } \\
\text { July } \\
\text { August }\end{array}$ & $\begin{array}{l}5,320 \mathrm{a} \\
8,200 \mathrm{abc} \\
5,400 \mathrm{a}\end{array}$ & $\begin{array}{l}6,800 \mathrm{ab} \\
7,560 \mathrm{abc} \\
9,880 \mathrm{~cd}\end{array}$ & $\begin{array}{l}7,440 \mathrm{abc} \\
8,960 \mathrm{bc} \\
8,920 \mathrm{bc}\end{array}$ & $\begin{array}{l}5,440 \mathrm{a} \\
9,080 \mathrm{bcd} \\
11,880 \mathrm{~d}\end{array}$ & $\begin{array}{l}6,240 a \\
8,440 b \\
9,040 b\end{array}$ \\
\hline Mean & $6,320 \mathrm{a}$ & $8,080 \mathrm{~b}$ & $8,440 \mathrm{~b}$ & $8,880 \mathrm{~b}$ & \\
\hline \multicolumn{6}{|c|}{ No fall burned and sampled 1970} \\
\hline $\begin{array}{l}\text { May } \\
\text { June } \\
\text { July } \\
\text { August }\end{array}$ & $\begin{array}{l}\quad 440 \mathrm{a} \\
3,320 \mathrm{bc} \\
7,880 \mathrm{f} \\
6,040 \mathrm{de}\end{array}$ & $\begin{array}{l}240 \mathrm{a} \\
3,320 \mathrm{bc} \\
7,520 \mathrm{f} \\
8,960 \mathrm{f}\end{array}$ & $\begin{array}{c}40 \mathrm{a} \\
1,680 \mathrm{ab} \\
8,800 \mathrm{f} \\
11,800 \mathrm{~g}\end{array}$ & $\begin{array}{l}\quad 0 \mathrm{a} \\
3,080 \mathrm{~b} \\
8,720 \mathrm{f} \\
5,200 \mathrm{~cd}\end{array}$ & $\begin{array}{r}200 \mathrm{a} \\
2,840 \mathrm{~b} \\
8,240 \mathrm{c} \\
8,000 \mathrm{c}\end{array}$ \\
\hline Mean & $4,440 \mathrm{a}$ & $5,000 \mathrm{a}$ & $5,600 \mathrm{a}$ & $4,240 \mathrm{a}$ & \\
\hline
\end{tabular}

1 Means followed by the same letter within a time of burning or within a group of overall means are not significantly different at the $5 \%$ level using Duncan's multiple range test.

2 Water levels represent the hydrological status at the time the study was delineated in June, 1969. Level $1=$ no standing water, $2=$ no standing water, $3=5 \mathrm{~cm}, 4=8 \mathrm{~cm}$ of water above the soil surface.

growth of whitetop occurred in 1969.

Water level had little influence on 1969 production at Petersburg, N. Dak., following a fall burn in 1968. A seasonal difference was noted for the first level (Table 3). Significant increases occurred in production among water levels for 1970. August production was greater in 1969 than in 1970 at the same site. These data support the hypothesis that burning tends to increase whitetop production.

May whitetop herbage production from the unburned site was $200 \mathrm{~kg} / \mathrm{ha}$ or half the production on the burned site for 1970 (Tables 2 and 3). Lack of April production on the unburned site in 1970 was attributed to accumulation of litter

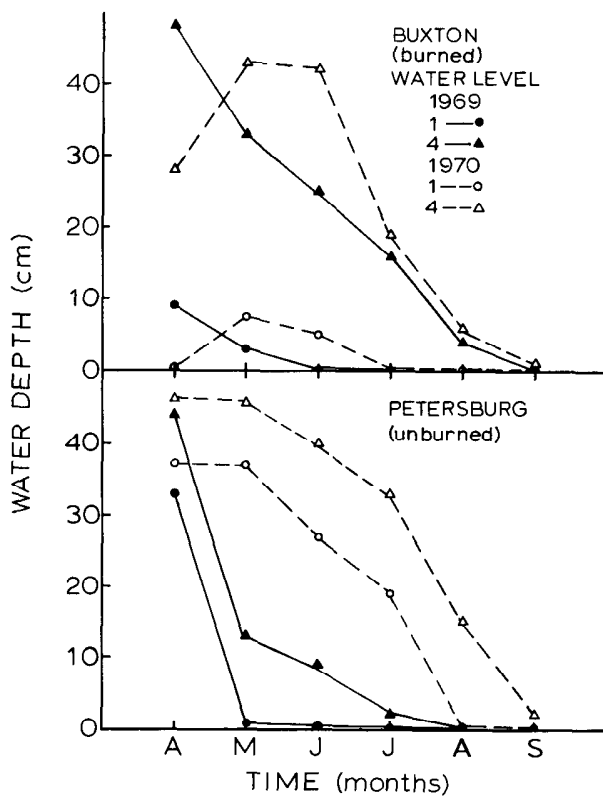

Fig. 2. Seasonal water level patterns for the study period on two whitetop dominated potholes in North Dakota. which reduced light penetration to the substrate. An average of $3,140 \mathrm{~kg} / \mathrm{ha}$ of accumulated oven-dry litter was obtained at the first level while $11,430 \mathrm{~kg} / \mathrm{ha}$ was collected at the deepest level in June 1970.

Water levels in the pothole at the onset of whitetop culm elongation were lower for the burned site than the unburned site in 1970 (Fig. 2). However, the water level increased approximately $15 \mathrm{~cm}$ between April and May harvests on the burned site. Water levels were approxmately the same in April for 1969 and 1970 on the unburned site. This indicates that water levels were not entirely responsible for the decreased production.

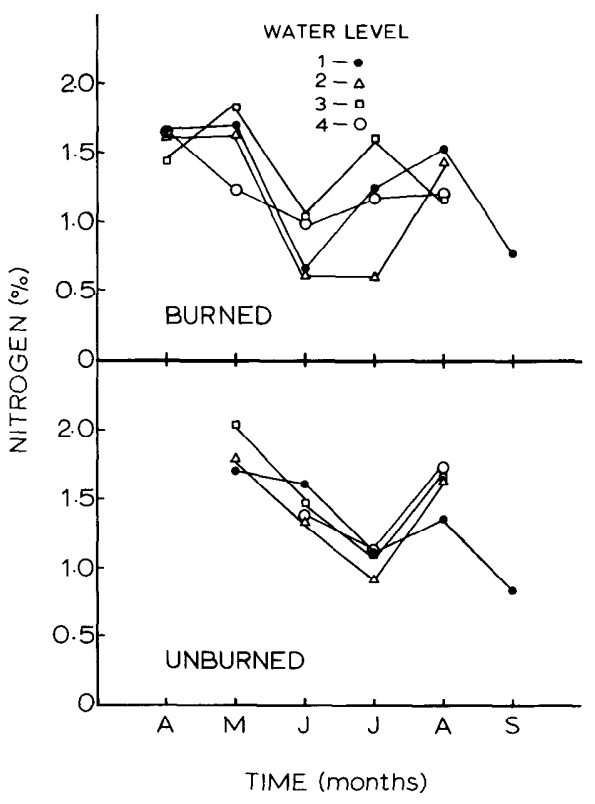

Fig. 3. Seasonal changes in nitrogen content in whitetop tissue in relation to water depth on burned and unburned sites in North Dakota in 1970 . 
Table 4. Nitrogen and basic cation content (\%) by weight in whitetop tissue from the seasonal productivity study sites near Petersburg (unburned) and Buxton (burned), North Dakota, during 1970.

\begin{tabular}{llllll}
\hline $\begin{array}{l}\text { Treatment } \\
\text { and month }\end{array}$ & $\mathrm{N}$ & $\mathrm{Ca}$ & $\mathrm{Mg}$ & $\mathrm{K}$ & $\mathrm{Na}\left(\times 10^{-2}\right)$ \\
\hline Unburned & & & & & \\
$\quad$ May & 2.03 & .15 & .12 & 2.9 & .24 \\
$\quad$ June & 1.47 & .14 & .07 & 1.9 & .50 \\
July & 1.20 & .15 & .08 & 1.4 & .20 \\
August & 1.65 & .18 & .11 & 1.0 & .50 \\
September & 0.84 & .29 & .13 & 0.5 & .40 \\
Burned & & & & & \\
April & 1.44 & .12 & .20 & 2.5 & .70 \\
May & 1.84 & .08 & .23 & 2.3 & .50 \\
June & 1.03 & .09 & .16 & 1.7 & .50 \\
July & 1.61 & .18 & .31 & 1.2 & .30 \\
August & 1.26 & .31 & .35 & 0.7 & .70 \\
September & 0.77 & .22 & .35 & 0.3 & .40 \\
\hline
\end{tabular}

A comparison of $\mathrm{N}$ values of plants growing at various water levels indicated phenological differences (Fig. 3). Herbage $\mathrm{N}$ content was about $0.5 \%$ higher from plant tissue growing at the third and fourth levels than for plants growing at the first and second levels in June on the burned site. Plant tissue tested from both locations decreased in $\mathrm{N}$ content at the onset of flowering (Table 4). This occurred in mid-June at the burned sites and early July at the unburned site. Delayed flowering was probably due to the later initiation of spring growth. Nitrogen content in whitetop tissue increased after flowering at both sites. A decrease was noted during senescence.

Calcium content of whitetop tissue varied little through the growing season, but increased at senescence (Table 4). Magnesium content declined from $0.12 \%$ in May to $0.08 \%$ in July on the unburned site, then increased to $0.13 \%$ by September. The $\mathrm{Mg}$ concentration dropped in June on tissue sampled from the burned site, followed by an increase through August. These fluctuations could have been responses to phenological changes. Differences in $\mathrm{Mg}$ concentrations of the burned and unburned sites (Table 4) were

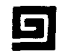

Longmont Seed Co.

We buy and sell western range grass and legume seed. Confront us with your needs.

Tel: (303) 776-1320

LONGMONT, COLORADO 80501 probably edaphic rather than due to burning. Variability of $\mathrm{Mg}$ concentrations within treatments (Table 1) substantiate this idea. Plant tissue from both sites declined in $\mathrm{K}$ content during the growing season. The highest $\mathrm{K}$ level occurred in the earliest growth stages and lowest prior to senescence. Nitrogen and $K$ are two elements which show greater concentrations in young shoots and a dilution in concentration as plant volume increases. Calcium and $\mathrm{Mg}$ are considered to enter plants at rates that prevent dilution (Smith, 1962). No pattern of Na concentration could be ascertained at either site relative to growth condition.

Whitetop is an excellent forage producer following burning and mowing. Forage protein content approach preflowering levels in late August, early September. Inundation of monodominant whitetop stands through flowering followed by drainage prior to mowing would provide maximum production. Proper management of whitetop would establish the species as an important forage grass of the Northern Great Plains.

\section{Literature Cited}

Blake, G. R. 1965. Bulk density. In C. A. Black,

\section{드}

\section{MOVINE?}

To assure uninterrupted receipt of the Journal of Range Management, please send your new address as soon as possible to SRM, 2120 S. Birch St., Denver, CO 80222. ed. Methods of soil analysis. p. 374-390. Part I. Amer. Soc. Agron., Madison, Wis.

Bouyoucos, C. J. 1962. Hydrometer method improved for making particle size analysis of soils. Agron. J. 54:464-465.

Bower, C. A., and L. V. Wilcox. 1965. Soluble salts. In C. A. Black, ed. Methods of soil analysis. p. 933-951. Part II. Amer. Soc. Agron., Madison, Wis.

Chapman, H. D. 1965. Cation exchange capacity. In C. A. Black, ed. Methods of soil analysis. P. 891-901. Part II. Amer. Soc. Agron., Madison, Wisc.

Clarke, S. E., and E. W. Tisdale. 1945. The chemical composition of native forage plants of southern Alberta and Saskatchewan in relation to grazing practices. Dominion of Canada, Dep. Agr. Pub. No. 769.

Coshy, H. E. 1964. Some yield characteristics of ranges as influenced by soil type and weather. J. Range Manage. 17:268-269.

Flint, R. F. 1957. Glacial and pleistocene geology. John Wiley and Sons, New York. $553 \mathrm{p}$.

Jackson, M. L. 1958. Soil chemical analysis. Prentice-Hall Inc., Englewood Cliffs, N. J. $498 \mathrm{p}$.

Martin, A. C., and F. H. Uhler. 1939. Food of game ducks in the United States and Canada. U. S. Dep. Agr. Tech. Bull. No. 634.

Richards, L. A. 1965. Physical conditions of water in soils. In C. A. Black, ed. Methods of soil analysis. p. 128-152. Part I. Amer. Soc. Agron., Madison, Wisc.

Smeins, F. E. 1967. The wetland vegetation of the Red River Valley and Drift Prairie regions of Minnesota, North Dakota, and Manitoba. Ph.D. Dissertation. Dep. of Plant Ecol., Univ. Saskatchewan, Saskatoon.

Smith, A. G., J. H. Stoudt, and J. B. Gollop. 1964. Prairie potholes and marshes. In J. J. Linduska, ed. Waterfowl tomorrow. p. 30-50. USDI, Washington, D. C.

Smith, P. F. 1962. Mineral analysis of plant tissues. ARPP 13:81-108.

Smith, A. L. 1971. An autecological study of the wetland grass, Scolochloa festucacea (Willd.) Link, Ph.D. Diss. Dep. Range Sci., Texas A\&M University.

Stewart, R. E., and H. A. Kantrud. 1969. Proposed classification of potholes in the glaciated prairie region. In Saskatoon wetlands scminar. p. 57-69. Can., Wildl. Serv. Rep. Ser. No. 6.

Zagrabaev, I., and V. Zenchenko. 1970. The utilization of Scolochloa festucacea scdge swamps for haymaking and grazing. Luga Pastischa 5:32-33.
드

\section{CLYDE ROBIN NATIVE SEEDS}

\author{
Castro Valley, California 94546
}

